\title{
ANTIOXIDANT ACTIVITY OF HALOPHILA OVALIS AND HALOPHILA BECCARII (HYDROCHARITACEAE): TWO IMPORTANT SEAGRASS SPECIES OF CHILIKA LAGOON, INDIA
}

\author{
SUBRAT KUMAR KAR ${ }^{1}$, SUPRAVA SAHOO ${ }^{2}$, BASUDEBA KAR ${ }^{2}$, SOUMENDRA KUMAR NAIK ${ }^{3}$, \\ PRATAP CHANDRA PANDA ${ }^{1 *}$
}

${ }^{1}$ Division of Taxonomy and Conservation, Regional Plant Resource Centre, Bhubaneswar, Odisha, India. ${ }^{2}$ Centre for Biotechnology,

Siksha 0 Anusandhan University, Bhubaneswar, Odisha, India. ${ }^{3}$ Department of Botany, Ravenshaw University, Cuttack, Odisha, India. Email: pcpanda2001@yahoo.co.in

Received: 03 August 2018, Revised and Accepted: 24 November 2018

ABSTRACT

Objective: The present study was undertaken to evaluate the total phenolic and flavonoid content and the antioxidant property of two important seagrass species namely, Halophila ovalis and Halophila beccarii occurring in Chilika lagoon, Odisha, India.

Methods: Total Phenolic Content (TPC) of the extracts of Halophila species was determined by Folin-Ciocalteu method with little modifications and the total flavonoid content (TFC) was measured by aluminum chloride colorimetric assay. The antioxidant activity of different extracts was investigated by DPPH and ABTS radical scavenging activity. $\mathrm{IC}_{50}$ values were calculated for the DPPH and ABTS methods.

Result: The study revealed that the methanol extract of $H$. ovalis has greater antioxidant activity than $H$. beccarii. Methanol extract of both the species (H. ovalis and $H$. beccarii) was found to possess high phenolic content at value of $70.25 \mathrm{mg}$ GAE/g of extract and $48.53 \mathrm{mg}$ GAE/g of extract respectively. Similarly flavonoid contents was found highest in methanol extract for both $\mathrm{H}$. ovalis (76.82 mg quercetin equivalent/g of extract) and $\mathrm{H}$. beccarii (64.28 mg quercetin equivalent/g of extract). The antioxidant activity of different extracts of these two species were evaluated using DPPH and ABTS radical assay. The methanol extract of both $H$. ovalis and $H$. beccarii showed high radical scavenging activity with $\mathrm{IC}_{50}$ values of $37.77 \mu \mathrm{g} / \mathrm{ml}_{\mathrm{l}}$ and $52.25 \mu \mathrm{g} / \mathrm{ml}$ for DPPH and $25.62 \mu \mathrm{g} / \mathrm{ml}$ and $45.45 \mu \mathrm{g} / \mathrm{ml}$ for ABTS respectively.

Conclusion: The study revealed the potential of the Halophila species as natural sources of antioxidants having considerable commercial importance.

Keywords: ABTS radical, 1, 1diphenyl-2-picryl hydrazyl radical, Flavonoids, Phenolics.

(C) 2019 The Authors. Published by Innovare Academic Sciences Pvt Ltd. This is an open access article under the CC BY license (http://creativecommons. org/licenses/by/4. 0/) DOI: http://dx.doi.org/10.22159/ajpcr.2019.v12i.3.28838

\section{INTRODUCTION}

Seagrasses, a group of marine flowering plants, inhabit the tidal and sub-tidal zones of shallow and sheltered localities of seas, gulfs, bays, backwaters, lagoons, and estuaries along temperate and tropical coastlines of the world [1,2]. With only about 72 species and 13 genera, seagrasses play key ecological roles in fisheries production, sediment accumulation, and stabilization [1,3,4] and have direct value to humanity as food, feed, green manure, and medicine [5-7]. Phytochemical analyses of seagrass species have shown that they are potential sources of antioxidants [8-11], antibacterial, antifungal and anti-inflammatory agents [8,12-14], and source of anticancer compounds [15].

Chilika, the largest tropical brackish water lagoon of Asia, is situated in the east coast of India in the state of Odisha. It is designated as a wetland of international importance under the Ramsar Convention and harbors rich flora and fauna characteristic of freshwater, brackish water, and marine habitats. As many as 5 seagrass species, namely Halophila ovalis, H. ovata, Halophila beccarii, Halodule pinifolia, and $H$. uninervis have been reported to occur in Chilika lagoon and the area under seagrass meadows are increasing after the opening of a new mouth connecting the lagoon to the Bay of Bengal [16]. As in other parts of the world, seagrasses of Chilika lagoon form dense meadows producing considerable biomass, provide excellent habitat for spawning fish and many juvenile marine invertebrates, perform multiple ecosystem services such as recycling of nutrients and stabilization of sediments. Although in a limited scale, the local fishermen communities use the whole plants of Halophila species as feed for buffaloes and goats after repeated washing, as packing materials for crabs and as green manure in their fields after decomposition. The leaf powder mixed with turmeric paste is also applied externally by fishermen for treatment of skin diseases.

In the face, increasing demand for antioxidants of plant origin, the importance of seagrasses as the natural source of antioxidants has increased many-fold. The antioxidant activity of plants might be due to the presence of phenolic compounds, flavonoids, $\alpha$-tocopherol, and carotenoids [17]. In spite of the biological potential of seagrasses, the antioxidant activity of several seagrass species has not yet been extensively studies [18] for different coastal habits of India. In the present study, the antioxidant potential of two seagrass species occurring in Chilika lagoon such as H. ovalis and Halophila berccarii has been assessed along with measurement of total phenolic and total flavonoid contents (TFC) in different solvent extracts. $H$. beccarii is a globally threatened species classified under "Vulnerable" category by IUCN, and the antioxidant activity of this species has so far not been evaluated. Although some seagrasses of the west coast and southern coastal regions of India have been investigated in respect of their antioxidant, antimicrobial and anti-inflammatory properties $[5,6,8,10,12,14]$, none of the species occurring in east coast of India which also includes Chilika lagoon, have been assessed for their antioxidant potential.

The present paper reports the antioxidant activities of two important seagrasses ( $H$. ovalis and $H$. berccarii) of Chilika lagoon, Odisha, India, along with an estimation of total phenolic and TFC in different solvent extracts. 


\section{MATERIALS AND METHODS}

\section{PLANT MATERIALS}

Whole plants of H. ovalis (R.Br.) Hook.f. and H. beccarii Asch. belonging to the family Hydrocharitaceae were collected from sandy shores of Chilika lagoon close to Pathara village $\left(19^{\circ} 37^{\prime} 10.1^{\prime \prime} \mathrm{N}\right.$ Lat., $85^{\circ} 08^{\prime} 45.9^{\prime \prime} \mathrm{E}$ Long.; Alt. $11.6 \mathrm{~m}$ ) of Ganjam district, Odisha by laying $1 \mathrm{~m} \times 1 \mathrm{~m}$ sample plots. The species were collected by our team and examined by Dr. P. C. panda and kept at RPRC herbarium having voucher no 10068 for $H$. ovalis and 10174 for $H$. beccarii. Plant samples were cleaned by repeated washing in lagoon water, removing clays, sands, and other epiphytic organisms growing on leaf blades. The plant samples were brought to the laboratory in zip lock polypack with the lagoon water to prevent dehydration. The samples then washed thoroughly with tap water to remove sands and debris, if any, leaves were removed manually and dried at room temperature.

\section{Preparation of extract}

The collected leaves were thoroughly washed, cut into pieces and dried for 15-20 days under shade. Then, the dried materials were grounded to a coarse powder. For extraction, different solvents such as methanol, n-hexane, and chloroform were added to $100 \mathrm{~g}$ of powdered leaves separately and placed in Soxhlet apparatus for $24 \mathrm{~h}$. The extracts were filtered with Whatman 40 filter paper and then concentrated using a rotary evaporator to give rise to a semisolid mass. Each solvent extraction method was repeated thrice for the purpose of accuracy. The residues obtained were stored in refrigerator for further analysis.

\section{Determination of total phenolic content (TPC)}

TPC of the extracts of two Halophila species was determined by the Folin-Ciocalteu method [19] using gallic acid as a standard phenolic compound. To record the readings within the standard curve range of $0.0-600 \mu \mathrm{g}$ of gallic acid/ml, the extracts were diluted with distilled water to a known concentration. In a test tube, $250 \mu \mathrm{l}$ of gallic acid solution or diluted extract was added to $1 \mathrm{ml}$ of distilled water followed by the addition of $250 \mu \mathrm{l}$ of Folin-Ciocalteu reagent. To allow complete reaction with the Folin-Ciocalteu reagent, the samples were shaken well for mixing and then allowed to stand at room temperature for $5 \mathrm{~min}$. Then, $2.5 \mathrm{ml}$ of aqueous solution of $7 \% \mathrm{Na}_{2} \mathrm{CO}_{3}$ was added to the test tube, and the final volume was made up to $6 \mathrm{ml}$ with distilled water. After incubating the samples for $90 \mathrm{~min}$, the absorbance of the subsequent blue colored solution was measured using spectrophotometer at $760 \mathrm{~nm}$. The result was expressed as mg of GAE/g of the extract using an equation that was obtained from the standard gallic acid graph. All the experiments were carried out in triplicates.

\section{Determination of TFC}

TFC of different extracts of two Halophila species was assessed by the protocol suggested by Ordon et al. [20] with little modification. This process is based on the establishment of a complex flavonoidaluminum. $1 \mathrm{ml}$ of ethanol solution of $2 \% \mathrm{AlCl}_{3}$ was mixed with $1 \mathrm{ml}$ of extract solution and kept in the dark for $1 \mathrm{~h}$ at room temperature. After incubation, the absorbance of the solution was measured at $420 \mathrm{~nm}$ using ultraviolet-visible (UV-VIS) spectrophotometer. From the calibration curve of Quercetin, TFC was calculated and expressed in terms of mg quercetin equivalent/g of the extract. All the determinations were performed in triplicates.

1, 1diphenyl-2-picryl hydrazyl (DPPH) radical scavenging activity Different extracts of Halophila species were subjected to DPPH radical scavenging activity, using the method of Blois with little modification [21]. According to this method, $1 \mathrm{ml}$ of extracts with different concentrations was added to $2 \mathrm{ml}$ of $0.1 \mathrm{mM}$ of freshly prepared DPPH methanol solution. The vigorously shaken mixture was left to stand for $30 \mathrm{~min}$ in the dark at room temperature. Then, the colorimetric changes of the resulting solution, i.e. from deep violet color to light yellow color were measured by a UV/Visible spectrophotometer at $517 \mathrm{~nm}$. In this experiment, ascorbic acid was used as positive control.
The absorbance of the DPPH radical without any samples (the control) was measured. All the observations were carried out in triplicate.

Radical scavenging activity was expressed as percentage inhibition of DPPH radical and was calculated using the following equation-

$$
\text { \%Inhibition }=\left[\left(\mathrm{A}_{\text {control }}-\mathrm{A}_{\text {test }}\right) / \mathrm{A}_{\text {control }}\right] \times 100
$$

Where, $A_{\text {control }}$ is the absorbance of the control and $A_{\text {test }}$ is the absorbance of samples.

The antioxidant activity of each sample was expressed in terms of IC $_{50}$ value calculated from the graph after plotting inhibition percentage against sample concentration.

\section{ABTS radical scavenging assay}

ABTS radical scavenging activity of different extracts of Halophila species was determined by following the method of Re et al. [22]. The working solution was prepared by mixing the two stock solutions, i.e. $7 \mathrm{mM}$ ABTS solution and $2.4 \mathrm{mM}$ potassium persulfate solution in equal quantities. Then, it was allowed to react for $12 \mathrm{~h}$ at room temperature in the dark. To obtain an absorbance of $0.706 \pm 0.001$ units at $734 \mathrm{~nm}$ using the spectrophotometer, the subsequent solution was then diluted by adding $1 \mathrm{ml}$ of freshly prepared ABTS solution. ABTS solution was freshly prepared for each experiment. $1 \mathrm{ml}$ of different extracts were mixed with $2.5 \mathrm{ml}$ of the ABTS solution and it was allowed to react. Then after $7 \mathrm{~min}$, the absorbance was measured at $734 \mathrm{~nm}$. BHT was used as positive control. The ABTS scavenging capacity of the extract was compared with the positive control and percentage inhibition was calculated as:

"ABTS radical scavenging activity $(\%)=\left[\left(\mathrm{A}_{\text {control }}-\mathrm{A}_{\text {test }}\right) / \mathrm{A}_{\text {control }}\right] \times 100$

Where $A_{\text {control }}$ is the absorbance of ABTS radical+methanol; $A_{\text {test }}$ is the absorbance of ABTS radical+sample."

\section{RESULTS AND DISCUSSION}

\section{Total phenolic and TFC}

In the present study, methanolic extract of $H$. ovalis was found to possess high phenolic (70.25 mg GAE/g of extract) and high flavonoid contents $(76.82 \mathrm{mg}$ quercetin equivalent/g of extract) as compared to $H$. beccarii. The phenolic content of $H$. ovalis of Chilika lagoon was significantly higher $(70.25 \mathrm{mg} \mathrm{GAE} / \mathrm{g}$ ) than that of the same species collected from Mandapam coast, Tamil Nadu, India (0.424 mg GAE/g) as reported by Ragupathi et al. [10]. The TPC of methanol extract of H. beccarii was $48.53 \mathrm{mg} \mathrm{GAE} / \mathrm{g}$ of extract, and TFC was $64.27 \mathrm{mg}$ quercetin equivalent/g of extract whereas the extract of $n$-hexane showed the lowest TPC and TFC contents for both the species (Table 1).

TPC was calculated using the standard curve of gallic acid (Fig. 1) (standard curve equation: $\mathrm{Y}=0.004 \mathrm{x}+0.063, \mathrm{R}^{2}=0.998$ ) and TFC was calculated using the standard curve of Quercetin (Fig. 2) (standard curve equation: $Y=0.013 x+0.487, R^{2}=0.886$ ). It was reported that plant secondary metabolites such as phenolics and flavonoids are the potent free radical scavengers [23]. Plant antioxidants which include phenolic compounds showed significant free radicals scavenging activity. Thus, the antioxidant potential of a sample can be accredited mostly to its phenolic compounds [24].

\section{Evaluation of antioxidant activity}

Antioxidant activity of plant extracts of $H$. ovalis and $H$. beccarii was studied through DPPH (2,2-diphenyl-1-picrylhydrazyl) and ABTS (2,2'-azino-bis(3-ethylbenzthiazoline-6-sulfonic acid) methods.

The antioxidant activity of different extracts obtained from $\mathrm{H}$. ovalis and $H$. beccarii was evaluated using DPPH radical assay. Here, the extracts showed substantial DPPH radical inhibiting property at $200 \mu \mathrm{g} / \mathrm{ml}$ concentration (Table 2). The DPPH radical scavenging activity of both the Halophila species compared with that of standard ascorbic acid was calculated. It was evidenced from the result that 
scavenging activity increased with the increase in the concentration of the samples.

The methanol extract of $H$. ovalis was able to reduce the stable violet DPPH radical to the yellow DPPH-H with low $\mathrm{IC}_{50}$ value, i.e. $38.26 \mu \mathrm{g} /$ $\mathrm{ml}$ whereas the $\mathrm{IC}_{50}$ value of methanol extract of $H$. beccarii is $94.26 \mu \mathrm{g} / \mathrm{ml}$. Lower $\mathrm{IC}_{50}$ value indicates a higher antioxidant activity. In both the species of Halophila, DPPH free radical scavenging capacity of extracts and positive controls was from strongest to weakest:ascorbic acid $>$ methanol extract $>$ chloroform extract $>n$ hexane extract.

In the present study, the extracts of Halophila species were effectively scavenge the ABTS radical. The methanol, chloroform, and n-hexane extracts of both the species exhibited potent scavenging effects against ABTS (Table 3)

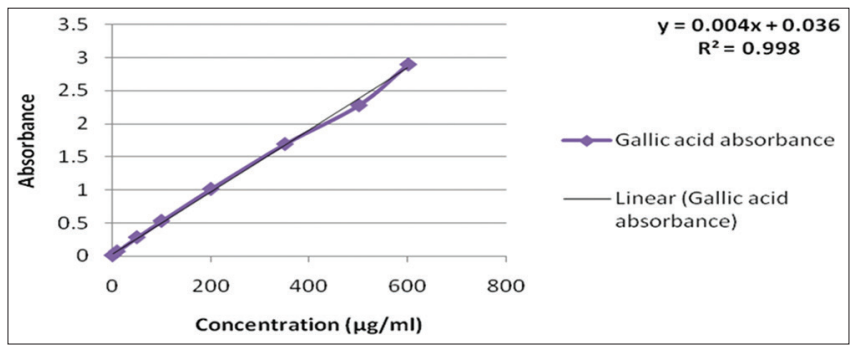

Fig. 1: Quercetin calibration curve for total flavonoid contents

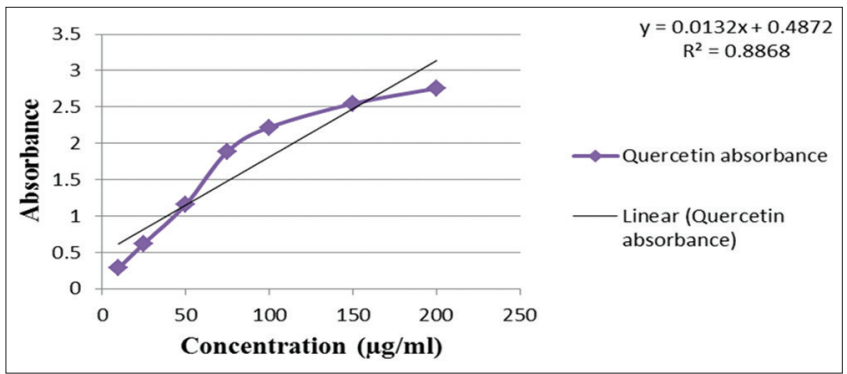

Fig.2 : Gallic acid calibration curve for total phenolic compounds
At $100 \mu \mathrm{g} / \mathrm{ml}$ concentration, the extracts exhibited higher inhibitory property against ABTS radicals. This assay is centered on the inhibition of the absorbance of radical cation $\mathrm{ABTS}^{+}$, which has a characteristic wavelength at $734 \mathrm{~nm}$, by antioxidants. The principle involves the relationship between $\mathrm{ABTS}$ and potassium persulfate to produce the ABTS radical cation $\left(\mathrm{ABTS}^{+}\right)$which is a blue-green chromogen. The colored radical is changed back to colorless ABTS when it reacted with antioxidant reductant [25]. The $\mathrm{IC}_{50}$ value of the methanol extract of $H$. ovalis and $H$. beccarii is $25.62 \mu \mathrm{g} / \mathrm{ml}$ and $45.45 \mu \mathrm{g} / \mathrm{ml}$, respectively (Table 4).

The extracts were able to reduce stable free radicals and hence can be correlated with the higher phenolics and flavonoids contents that are known to be potential antioxidants [26,27]. It is well known that the antioxidant activity of plant extracts containing polyphenol components is due to the capacity to be donors of hydrogen atoms or electrons and to capture the free radicals. Hence, it can be concluded that the higher antioxidant activity of methanol extract of both the Halophila species observed in both DPPH and ABTS method might be due to higher phenolics and flavonoids content. The study showed that methanol extract of $H$. ovalis and $H$. beccarii collected from Chilika lagoon exhibited $50 \%$ of scavenging activity on DPPH radicals at $37.77 \mu \mathrm{g} / \mathrm{ml}$ and $25.62 \mu \mathrm{g} / \mathrm{ml}$ and ABTS radicals at $52.25 \mu \mathrm{g} / \mathrm{ml}$ and $45.45 \mu \mathrm{g} / \mathrm{ml}$, respectively. Relatively less scavenging activity has been reported in $H$. ovalis from Mandapam coast, Tamil Nadu by Rengasamy et al. [10] and from Chunnambar estuary, Pondicherry by Yuvaraj et al. [14]. Hence, we consider that the higher antioxidant activity of the extracts might be due to its high content of phenolics and flavonoids in $\mathrm{H}$. ovalis occurring in Chilika lagoon in eastern India. However, till date, there is no published report on the antioxidant activity of $H$. beccarii in India or elsewhere.

\section{CONCLUSION}

The antioxidant activity of extracts of $H$. ovalis and $H$. beccarii two seagrass species of Chilika lagoon was evaluated on the basis of DPPH and ABTS radical scavenging activities. The result of the present study revealed that the methanolic extract of $H$. ovalis of Chilika lagoon exhibited the highest antioxidant activity in comparison to the antioxidant potential of this species in other habitats reported so far. The methanolic extract of $H$. ovalis contained a high level of phenolics and flavonoids, which can be attributed to strong antioxidant activity observed against ABTS and DPPH radicals. This strong antioxidant property identifies the particular seagrass species as a potential source

Table 1: TPC and TFC of H. ovalis and H. beccarii

\begin{tabular}{|c|c|c|c|c|}
\hline \multirow[t]{2}{*}{ Solvent extracts } & \multicolumn{2}{|l|}{ H. ovalis } & \multicolumn{2}{|l|}{ H. beccarii } \\
\hline & TPC (mg GAE/g) & TFC (mg quercetin equivalent/g) & TPC (mg GAE/g) & TFC (mg quercetin equivalent/g) \\
\hline Methanol & $70.25 \pm 0.34$ & $76.82 \pm 0.11$ & $48.53 \pm 0.32$ & $64.27 \pm 0.84$ \\
\hline $\mathrm{N}$ hexane & $53.44 \pm 0.18$ & $47.83 \pm 0.22$ & $23.62 \pm 0.95$ & $34.55 \pm 0.58$ \\
\hline Chloroform & $62.87 \pm 0.71$ & $65.25 \pm 0.85$ & $30.33 \pm 0.76$ & $48.69 \pm 0.34$ \\
\hline
\end{tabular}

Data represented as mean \pm standard deviation $(n=3)$, TPC: Total phenolic content, TFC: Total flavonoid contents, TPC: Total phenolic content, GAE: Gallic acid

equivalents, H. ovalis: Halophila ovalis, H. beccarii: Halophila beccarii,

Table 2: Percentage of inhibition of $H$. ovalis and H. beccarii revealed from DPPH Asaay

\begin{tabular}{|c|c|c|c|c|c|c|c|}
\hline \multirow[t]{3}{*}{ Concentration $(\mu \mathrm{g} / \mathrm{ml})$} & \multicolumn{7}{|l|}{$\%$ Inhibition } \\
\hline & \multirow{2}{*}{$\begin{array}{l}\text { Ascorbic acid } \\
\text { (positive control) }\end{array}$} & \multicolumn{2}{|l|}{ Methanol } & \multicolumn{2}{|l|}{$\mathrm{N}$ hexane } & \multicolumn{2}{|l|}{ Chloroform } \\
\hline & & H. ovalis & H. beccarii & H. ovalis & H. beccarii & H. ovalis & H. beccarii \\
\hline 1 & $4.32 \pm 0.48$ & $9.96 \pm 0.63$ & $8.43 \pm 0.69$ & $3.87 \pm 0.35$ & $3.75 \pm 0.67$ & $5.22 \pm 0.8$ & $6.48 \pm 0.43$ \\
\hline 10 & $74.81 \pm 0.33$ & $21.63 \pm 0.48$ & $17.75 \pm 0.53$ & $9.18 \pm 0.7$ & $7.75 \pm 0.22$ & $10.58 \pm 0.49$ & $10.57 \pm 0.38$ \\
\hline 20 & $80.15 \pm 0.74$ & $33.87 \pm 0.22$ & $32.65 \pm 0.38$ & $25.46 \pm 0.83$ & $18.54 \pm 0.56$ & $26.61 \pm 0.15$ & $19.66 \pm 0.86$ \\
\hline 50 & $88.72 \pm 0.43$ & $66.93 \pm 0.7$ & $40.81 \pm 0.91$ & $39.55 \pm 0.96$ & $33.95 \pm 0.64$ & $38.97 \pm 0.7$ & $29.28 \pm 0.32$ \\
\hline 100 & $91.45 \pm 0.18$ & $99.55 \pm 0.46$ & $53.06 \pm 0.13$ & $48.34 \pm 0.77$ & $40.21 \pm 0.76$ & $53.19 \pm 0.55$ & $40.34 \pm 0.61$ \\
\hline 200 & $99.52 \pm 0.4$ & $99.98 \pm 0.23$ & $89.38 \pm 0.78$ & $60.52 \pm 0.56$ & $60.78 \pm 0.37$ & $83.76 \pm 0.62$ & $68.73 \pm 0.18$ \\
\hline
\end{tabular}

Data represented as mean \pm standard deviation $(\mathrm{n}=3)$, H. ovalis: Halophila ovalis, H. beccarii: Halophila beccarii 
Table 3: Percentage of inhibition of $\boldsymbol{H}$. ovalis and $\boldsymbol{H}$. beccarii revealed from ABTS assay

\begin{tabular}{|c|c|c|c|c|c|c|c|}
\hline \multirow[t]{3}{*}{ Concentration $(\mu \mathrm{g} / \mathrm{ml})$} & \multicolumn{7}{|l|}{$\%$ Inhibition } \\
\hline & \multirow{2}{*}{$\begin{array}{l}\text { Ascorbic acid } \\
\text { (positive control) }\end{array}$} & \multicolumn{2}{|l|}{ Methanol } & \multicolumn{2}{|l|}{$\mathrm{N}$ hexane } & \multicolumn{2}{|l|}{ Chloroform } \\
\hline & & H. ovalis & H. beccarii & H. ovalis & H. beccarii & H. ovalis & H. beccarii \\
\hline 1 & $5.32 \pm 0.54$ & $12.96 \pm 0.31$ & $10.35 \pm 0.42$ & $2.87 \pm 0.37$ & $4.56 \pm 0.74$ & $5.22 \pm 0.9$ & $8.83 \pm 0.58$ \\
\hline 10 & $67.61 \pm 0.29$ & $29.96 \pm 0.23$ & $20.75 \pm 0.38$ & $10.85 \pm 0.43$ & $11.67 \pm 0.44$ & $19.58 \pm 0.24$ & $14.54 \pm 0.82$ \\
\hline 20 & $80.52 \pm 0.9$ & $43.67 \pm 0.19$ & $36.23 \pm 0.15$ & $27.68 \pm 0.71$ & $21.48 \pm 0.31$ & $33.91 \pm 0.45$ & $22.86 \pm 0.67$ \\
\hline 50 & $86.28 \pm 0.47$ & $70.34 \pm 0.63$ & $54.71 \pm 0.34$ & $42.35 \pm 0.7$ & $43.95 \pm 0.55$ & $53.22 \pm 0.74$ & $37.78 \pm 0.55$ \\
\hline 100 & $95.33 \pm 0.34$ & $99.55 \pm 0.51$ & $69.64 \pm 0.63$ & $58.34 \pm 0.3$ & $60.15 \pm 0.12$ & $64.79 \pm 0.4$ & $46.34 \pm 0.63$ \\
\hline 200 & $99.42 \pm 0.42$ & $99.98 \pm 0.66$ & $86.83 \pm 0.93$ & $69.52 \pm 0.23$ & $68.77 \pm 0.47$ & $80.76 \pm 0.8$ & $65.73 \pm 0.92$ \\
\hline
\end{tabular}

Data represented as mean \pm standard deviation $(\mathrm{n}=3)$, H. ovalis: Halophila ovalis, H. beccarii: Halophila beccarii

Table 4: $\mathrm{IC}_{50}$ values of $H$. ovalis and $H$. beccarii

\begin{tabular}{|c|c|c|c|c|}
\hline \multirow[t]{2}{*}{ Solvent extracts } & \multicolumn{2}{|c|}{$\mathrm{DPPH}(\mu \mathrm{g} / \mathrm{ml})$} & \multicolumn{2}{|c|}{ ABTS $(\mu \mathrm{g} / \mathrm{ml})$} \\
\hline & H. ovalis & H. beccarii & H. ovalis & H. beccarii \\
\hline Methanol & 37.77 & 52.25 & 25.62 & 45.45 \\
\hline $\mathrm{N}$ hexane & 100.20 & 102.02 & 52.45 & 51.96 \\
\hline Chloroform & 53.14 & 102.74 & 30.34 & 100.71 \\
\hline Positive control (ascorbic acid) & 5.55 & & 6.23 & \\
\hline
\end{tabular}

H. ovalis: Halophila ovalis, H. beccarii: Halophila beccarii

of natural antioxidant for protection against several oxidative stressrelated diseases. Besides, the antioxidant activity of $H$. beccarii reported here for the first time will open up similar research in other parts of the world and help in bioprospecting and conservation of this globally threatened plant species.

\section{AUTHORS' CONTRIBUTIONS}

PCP conceived the project and taxonomically identified the species. PCP and SKN supervised and guided the research work and preparation of the manuscript. SKK collected and processed the samples and performed analysis of extracts with different solvents. SS and BK studied the scavenging activity and analyzed the data. BK, SKK, and SS interpreted the data and prepared the manuscript. All authors read and approved the final manuscript.

\section{CONFLICTS OF INTEREST}

The authors report no conflicts of interest regarding this manuscript.

\section{REFERENCES}

1. Green EP, Short FT. World Atlas of Seagrasses. Berkeley: University California Press; 2003.

2. Short FT, Coles RG, Pergent-Martini C. Global seagrass distribution. In: Short FT, Coles RG, editors. Global Seagrass Research Methods. Amsterdam: Elsevier Science BV; 2001. p. 5-30.

3. Larkum T, Orth RJ, Duarte CM, editors. Seagrasses: Biology, Ecology and Conservation. The Netherlands: Springer; 2006.

4. Rönnbäck P, Kautsky N, Pihl L, Troell M, Söderqvist T, Wennhage H, et al. Ecosystem goods and services from Swedish coastal habitats: Identification, valuation, and implications of ecosystem shifts. Ambio 2007;36:534-44.

5. Newmaster AF, Berg KJ, Ragupathy S, Palanisamy M, Sambandan K, Newmaster SG. Local knowledge and conservation of seagrasses in the Tamil Nadu state of India. J Ethnobiol Ethnomed 2011;7:37.

6. Ragupathi KR, Radjessegarin A, Perumal A. Seagrasses as potential source of medicinal food ingredients: Nutritional analysis and multivariate approach. Biomed Prevent Nutr 2013;3:375-80.

7. Wyllie-Echeverria S, Cox PA. The seagrass (Zostera marina [Zosteraceae]) industry of Nova Scotia (1907-1960). Econ Bot 1999;53:419-26.

8. Ragupathi KR, Radjessegarin A, Perumal A. In vitro antioxidant activities of Enhalus acoroides. Asia Pac J Trop Med 2010;11:898-901.

9. Ragupathi KR, Radjessegarin A, Meenakshi S, Perumal A. Thin layer chromatography analysis of antioxidant constituents of seagrasses of gulf of mannar biosphere reserve, South India. Int J Chem Tech Res 2010;2:1526-30.

10. Rengasamy RR, Rajasekaran A, Micheline GD, Perumal A. Antioxidant activity of seagrasses of the Mandapam coast, India. Pharm Biol 2012;50:182-7.

11. Ragupathi KR, Radjessegarin A, Thirunavukarasu T, Perumal PC. Phytochemical constituents, antioxidant properties and p-coumaric acid analysis in some seagrasses. Food Res Int 2013;54:1229-36.

12. Alam K, Agua T, Maven H, Taie R, Rao KS, Burrows I. Preliminary screening of seaweeds, seagrass and lemongrass oil from Papua New Guinea for antimicrobial and antifungal activity. Pharm Biol 1994;32:396- 9 .

13. Puglisi MP, Engel S, Jensen PR, Fenical W. Antimicrobial activities of extracts from Indo-pacific marine plants against marine pathogens and saprophytes. Mar Biol 2007;150:531-40.

14. Yuvaraj N, Kanmani P, Satishkumar R, Paari A, Pattukumar V, Arul V, et al. Seagrass as a potential source of natural antioxidant and antiinflammatory agents. Pharm Biol 2012;50:458-67.

15. Folmer F, Jaspars M, Dicato M, Diederich M. Photosynthetic marine organisms as a source of anticancer compounds. Phytochem Rev 2010;9:557-79.

16. Pattnaik AK, Panda PC, Patnaik SN. The diversity, distribution and taxonomy of sea grasses of Chilika lagoon, Orissa - The largest brackish water lagoon of India. J Econ Taxon Bot 2008;32:381-92.

17. Geetha T, Malhotra V, Chopra K, Kaur IP. Antimutagenic and antioxidant/prooxidant activity of quercetin. Indian $\mathrm{J}$ Expt Biol 2005;43:61-7

18. De S, Devasagayam PA, Adhikari S, Menon VP. Antioxidant properties of a novel marine analogue of dendrodoine. Broadcast Audience Res Council News Lett 2006;273:511-2.

19. Singleton VL, Orthofer R, Lamueala-Raventos RM. Analysis of total phenols and other oxidation substrates and the oxidants by means of folin-ciocalteu reagent. Methods Enzymol 1999;299:152-78.

20. Ordon EA, Gomez JD, Vattuone MA, Isla MI. Antioxidant activities of Sechium edule (Jacq). Food Chem 2006;97:452-8.

21. Blois MS. Antioxidant determinations by the use of a stable free radical. Nature 1958:181:1199-200.

22. Re R, Pellegrini N, Proteggente A, Pannala A, Yang M, Rice-Evans C, et al. Antioxidant activity applying an improved ABTS radical cation decolorization assay. Free Radic Biol Med 1999;26:1231-7.

23. Mathew $\mathrm{S}, \mathrm{Abraham} \mathrm{TE}$. In vitro antioxidant activity and scavenging effects of Cinnamommum verum leaf extract assayed by different methodologies. Food Chem Toxicol 2006;44:198-206.

24. Huang Z, Wang B, Eaves DH, Shikany JM, Pace RD. Total phenolics and antioxidant capacity of indigenous vegetables in the Southeast Unites States: Alabama colloboration for cardiovascular equity project. Int J Food Sci Nutr 2009;60:100-8. 
25. Sreejayan M, Rao NA. Free radical scavenging activity of curcuminoids. Arzneimittle Forsch Drug Res 1996;6:169-71.

26. Sahoo S, Singh S, Nayak S. Chemical composition, antioxidant and antimicrobial activity of essential oil and extract of Alpinia malaccensis roscoe (Zingiberaceae). Int J Pharm Pharm Sci 2014;6:183-8.

27. Mohanty S, Parida R, Sandeep IS, Sahoo S, Nayak S. Evaluation of drug yielding potential of micropropagated Curcuma aromatica. Int J Pharm Pharm Sci 2015;7:71-6. 